\title{
갑상선의 초음파 진단
}

고신대학교 의과대학 내과학교실

최 영 식

\section{서 론}

갑상선 및 경부에서 real time 초음파검사(US) 가 이 용된 것은 25 년 정도 되었고, 갑상선 결절의 크기, 내부 성상 및 주위 조직과의 관계를 알 수 있으므로 결절의 진단에 있어서 촉지나 스캔보다 나음에도 불구하고, 아 직 내분비의사들에게는 잘 사용되지 않고 있다고 한다. ${ }^{1)}$ 이는 방사선의사들의 갑상선과 부갑상선 질환의 관리에 있어 US의 유용성에 대한 이해의 부족과 내분비의사들 이 갑상선질환의 진단에 $\mathrm{US}$ 가 제한점이 많다는 잘못된 인식에 의한다고 한다. 이러한 잘못된 인식의 원인은 1982년 van Herle 등 ${ }^{2}$ 의 Annals Internal Medicine에 서 갑상선 결절의 악성과 양성을 감별하는데 세침흡인세 포검사(FNA)가 US 보다 훨씬 더 특이적이라는 보고 때문이라고 한다. 이 논문은 그 후 FNA가 US 보다 더 낫다는 잘못된 결론을 유도하게 되었다고 한다. 그러나 1990 년대 이후 몇몇 내분비의사들에 의해 갑상선결절 의 진단에 US가 사용되기 시작하였고, 갑상선암을 예측 할 수 있는 초음파 변수들도 알게 되었으며, 특히 Chernobyl 원전 사고 후 수습 과정에서 취학전 아동에서 일 반인구에 비해 100 배 정도 증가한 갑상선암의 조기진 단과 술후 추적 검사에 갑상선 초음파검사를 이용하여 사망률을 감소시킬 수 있었다.

갑상선 초음파검사는 향후 갑상선 질환의 관리에 내 과의사에게 청진기와 같은 역할을 할 수 있으므로 본 글 에서는 갑상선 초음파검사의 유용성과 갑상선질환의 초 음파적 소견 등을 살펴보고자 한다.

교신저자 : 최영식, 602-702 부산광역시 서구 암남동 34 고신대학교 의과대학 내과학교실

전화 : (051) 990-6102 · 전송 : (051) 248-5686

E-mail:yschoi@ns.Kosinmed.or.kr

\section{갑상선질환에서 초음파검사의 장, 단점}

갑상선 초음파 검사는 다른 검사에 비해 방사선의 피 폭이 없고, 검사가 단순하고 반복하기 쉬운 초음파검사 자체의 장점 외에도 갑상선 체적 및 결절의 크기 측정, 잠재(미소) 갑상선 결절의 발견, 갑상선결절의 특성 및 내부 성상(낭성, 혼합성 및 고형성), 전이성 림프절 진 단 및 갑상선암의 주위 침윤 관찰, 갑상선암 수술 후 추 적검사, Doppler 초음파를 이용하여 혈관 분포 확인, 초 음파 유도하 FNA 가능 등의 장점이 있다. 반면 화상 해 독의 훈련이 필요하며, 비만하거나 목을 신전시키기 힘 든 환자에서는 진단이 힘든 단점이 있다.

\section{정상 갑상선의 초음파 단층상}

갑상선 초음파검사에서 탐촉자는 $5 \mathrm{MHz}$ 에서 $10 \mathrm{MHz}$ 까지 여러 가지를 사용할 수 있다. 영상을 주로 횡단주사 (transverse scan)와 사단주사(oblique scan)를 이용 하여 얻으며, 진피와 superficial cervical fascia는 echo 가 강하게 보이나, 전경근(anterior cervical muscle)과 흉쇄유돌근(sternocleidomastoid muscle)은 저에코 음 영(hypoechoic)을 보인다(Fig. 1).

\section{초음파 검사를 이용한 갑상선질환의 진단}

외래에서 갑상선을 진료할 대부분 진찰과 생화학검사 를 이용하며 경우에 따라 동위원소검사를 시행한다. 그 러나 초음파 소견을 잘 활용하면 진단에 매우 유용하다. 본란에서는 임상에서 흔히 접하는 갑상선질환을 편의상 국소성(결절성) 갑상선질환과 미만성(비결절성) 갑상선 질환으로 분류하여 각각의 갑상선질환에 대한 초음파 소견을 설명하려고 한다. 또한 갑상선 결절의 초음파상 
Fig. 1. Nomal ultrasonographic anatomy of thyroid gland.

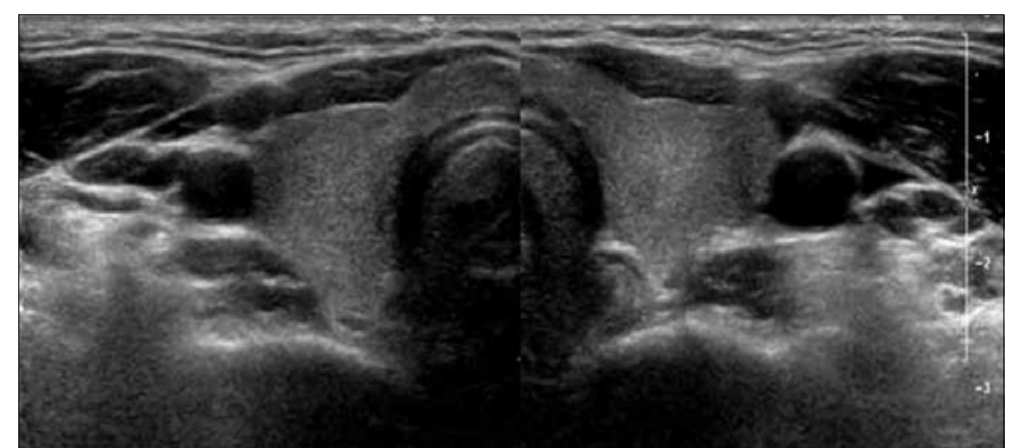

분류는 결절의 내부 성상에 따라 낭성(cystic)병변, 혼 합성 (complex, mixed echo) 병변, 고형성 (solid) 병변으 로 나누며, 고형병변은 주변 갑상선조직의 echo와 비교 하여 저에코(hypoechoic), 등에코(isoechoic), 고에코 (hyperechoic) 병변으로 나누나 본란에서는 갑상선결 절을 병리학적으로 양성결절과 악성결절로 분류한 후 초음파소견을 살펴보았다.

\section{결절성(국소성) 갑상선질환의 초음파적 진단}

갑상선결절은 보고자마다 차이는 있으나, 북미의 역학 적 연구(Framingham database)에 의하면 성인의 4 $7 \%$ 에서 나타나며, 일생 동안 갑상선결절이 발생할 확 률은 5 10\%로 추정된다고 한다. ${ }^{3}$ 또한 고해상능 갑상 선 초음파 검사에서는 $10 \sim 40 \%$, 사체부검시에는 촉지되 지 않은 작은 결절을 포함할 경우 $75 \%$ 정도 발견되는 임상적으로 흔한 질환이다. ${ }^{4)}$ 갑상선결절의 대부분은 양 성종양이며, 수술하거나, 세침흡인세포 검사를 시행한 경 우 갑상선결절에서의 악성종양의 빈도는 1.5 38.1\%로 보고되어 있다. ${ }^{5)}$ 갑상선 결절이 양성인 경우 갑상선 호 르몬(T4) 억제요법을 시행하거나 추적 관찰을 하는데 반하여, 악성결절은 수술 및 적극적인 치료가 필요하므 로, 갑상선결절의 악성 여부를 감별하는 것은 중요하다. 최근 초음파 기기의 발달로 더 양호한 영상을 획득할 수
있을 뿐 아니라, 초음파검사가 빈번히 이용됨에 따라 초 음파검사 소견을 이용하여 악성여부를 판단할 수 있는 여러 변수들에 대한 연구들이 보고되고 있으며, 연구자에 따라 다소의 차이는 있으나 약 $70 \%$ 정도까지 진단이 가 능하다.

\section{양성결절성 질환의 초음파 소견}

낭 종(Cyst)

한층의 앏은 피막과 같은 echo가 있고, 내부 echo를 인 지하지 못하는 원형 또는 타원형의 종류상을 보이며, 후 방 echo의 증가를 보일 수 있다(Fig. 2). 초음파검사를 하다보면 낭포성 병변 안에 hyperechoic 한 돌기를 관 찰되며 이 경우 악성결절을 의심하는 경우가 많으나 대 부분 양성 종양이다.

또한 작은 크기의 낭종에 있는 콜로이드가 석회화 반 점처럼 보이는 comet tail sign을 관찰할 수 있는데, 미 세석회화와 감별이 요한다. 미세석회화는 후방음영 (acaustic shadow)이 있으나 comet tail sign의 경우에는 후 방음영이 없다(Fig. 3). 반면 병변 부위에 점상의 석회 화가 보일 경우 악성 (cystic papillary carcinoma)을 의 심할 수 있으며(Fig. 4), 초음파 유도하 세침흡인세포를 시행하면 병변부위를 정확히 검사할 수 있다. 


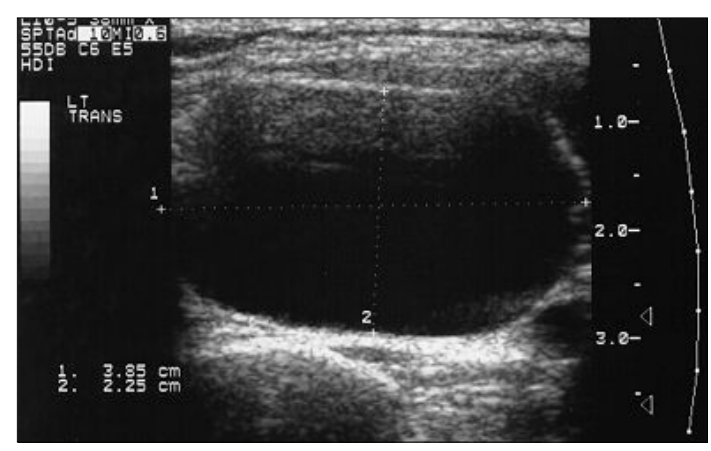

Fig. 2. Cyst.

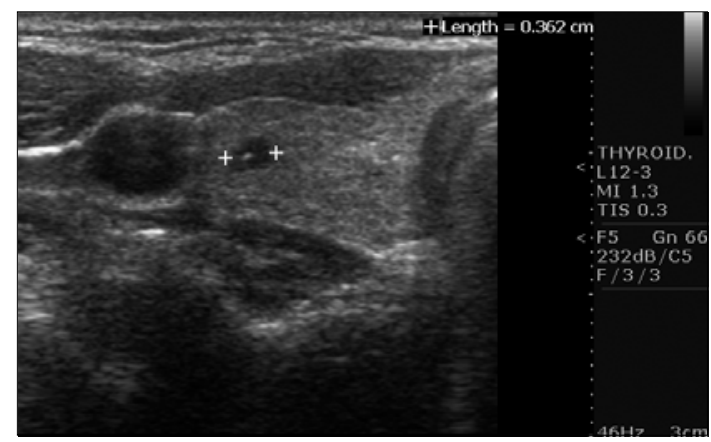

Fig. 3. Comet tail sign.

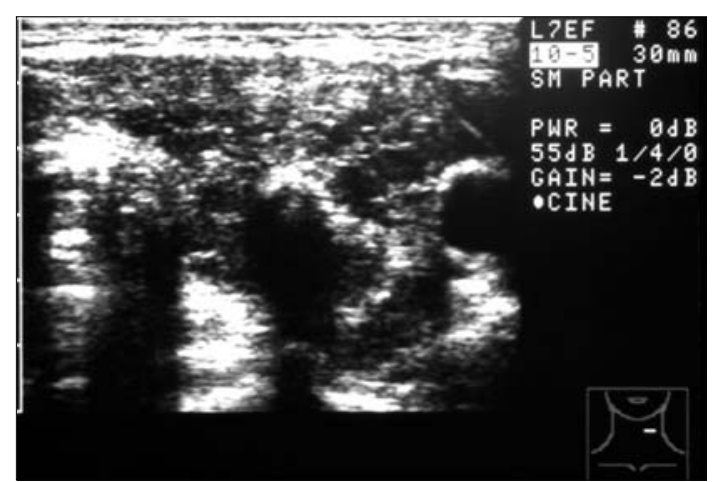

Fig. 4. Cystic papillary carcinoama.

선종양 갑상선종(Adenomatous goiter, colloidal goiter) 갑상선 양성결절성 질환의 대부분 선종양 갑상선종이 며, 약 $90 \%$ 를 차지한다. 또한 선종양 갑상선종은 초음 파 검사상 대부분 혼합성(complex type) 병변을 보인다. 선종양 갑상선종은 colloid가 풍부하고 피막이 없거나 불 완전하며(Fig. 5), 특히 sponge sign은 양성 종양으로 진단이 가능하다(Fig. 6). 반면 한쪽 엽에 고립된 경우는

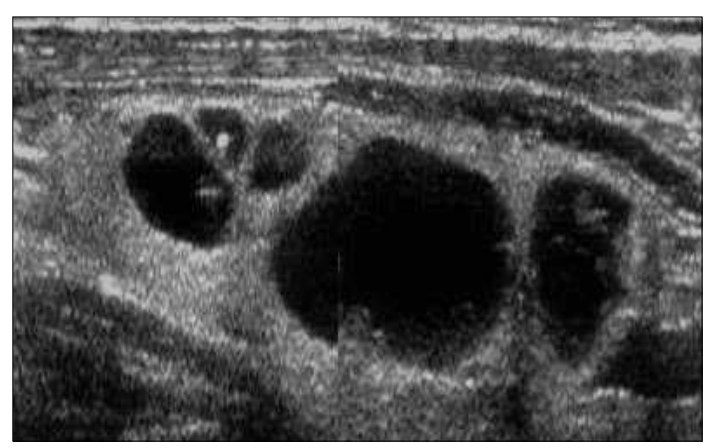

Fig. 5. Adenomatous goiter.

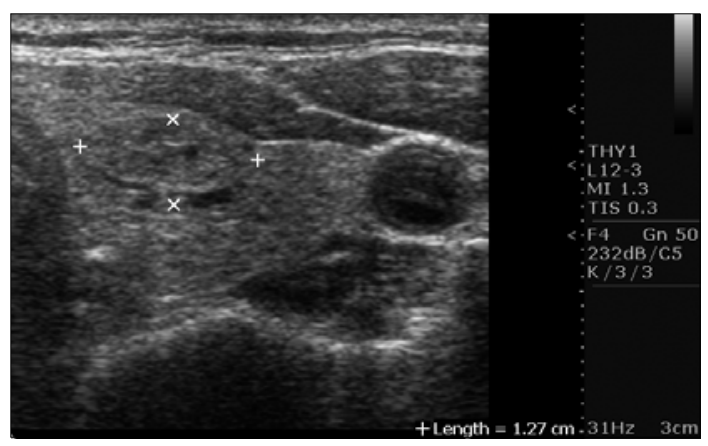

Fig. 6. Sponge sign.

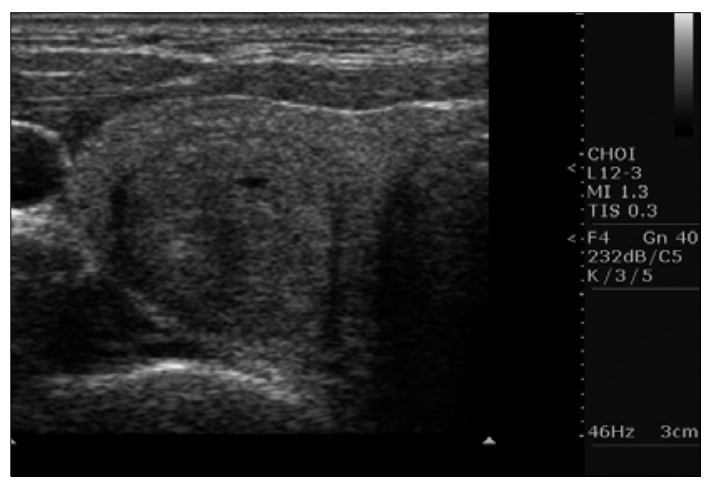

Fig. 7. Follicular adenoma with halo sign.

선종과 감별이 어렵다.

선 종(Adenoma)

선종은 colloid가 드물고, 피막이 잘 발달 해있다. 원형, 타원형 등의 모양을 보이며, 비교적 균일한 내부 echo를 보이고, 변연부에 저 echo 음영부위(halo)를 동반하는 경 우가 많다(Fig. 7). 선종내부에서 변성괴사가 발생하면 내 
부의 echo가 소실되기도 한다. 여포선종은 FNA에서 여포 선암과 감별이 되지 않아 대개 수술을 권하는 경우가 많다.

악성결절에서의 초음파 소견

\section{유두선암}

유두선암의 초음파 소견으로는 미세석회화(Fig. 8), 불 규칙한 변연부, 피막 침범(Fig. 9), 결절의 세로길이가 가 로길이 보다 큰 경우 및 저에코성 음영(전경근의 에코와 유사한 저에코 음영) 등이 알려져 있다. ${ }^{67)}$

석회화는 갑상선의 양성종양 뿐 아니라, 유두선암, 수 질암 및 역형성암 등에서도 흔히 발견된다. ${ }^{8)}$ 그러나 그 레이브스병, 선종양종(adenomatous goiter), 낭종성 갑 상선질환에 동반된 석회화는 비록 원인 질환이 양성질환 이라도 석회화가 없는 결절보다 더 악성을 의심하여야 한 다고 한다. ${ }^{9)}$ 본 교실의 연구에서 석회화는 악성종양 89

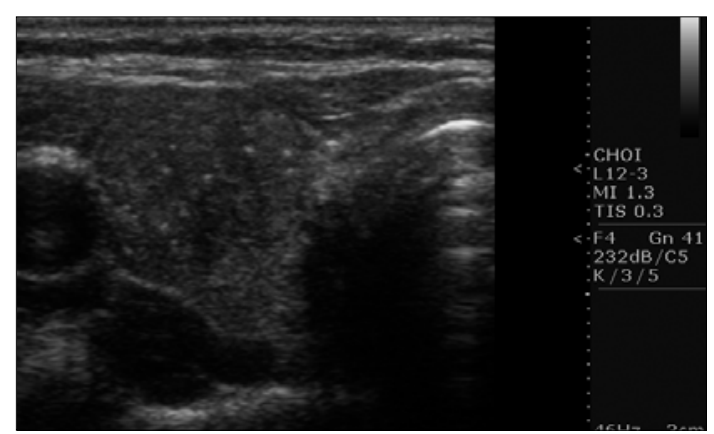

Fig. 8. Mic roc a lcific ation.
예 중 53예(59.6\%)에서 양성을 보였으며, 석회화를 보 인 59예 중 악성종양은 53예(89.8\%)로 악성 종양에서 석회화의 빈도가 높음을 알 수 있었다(Table 1).

초음파검사에서 악성을 시사하는 각각의 변수들과 병리 조직 소견과의 민감도도 석회화 $(55.1 \%)$, 불규칙한 변연 부 $(49.4 \%)$, 결절의 세로길이가 가로길이 보다 큰 경우 $(33.7 \%)$, 피막을 침범한 경우 $(8.9 \%)$ 로 석회화가 가장 높았고, 다중회귀 분석결과에서도 석회화와 불규칙한 변 연부가 유의한 것으로 나타났다(Table 2).

갑상선암을 시사하는 석회화 양상으로 점상 석회화(fine -stippled, punctated) 와 미세석회화 등이 있다. 본교실 의 연구에서 의하면 갑상선 악성결절에 동반된 석회화 53 예 중 단일 석회화군은 6예(11.3\%), 점상 석회화군은 22 예(41.5\%), 무정형 석회화군은 25예(47.2\%)로 점상 석 회화군과 무정형 석회화군에서 악성결절의 빈도가 유의 하게 높았으며, 점상 석회화군 23예 중 22예(95.6\%),

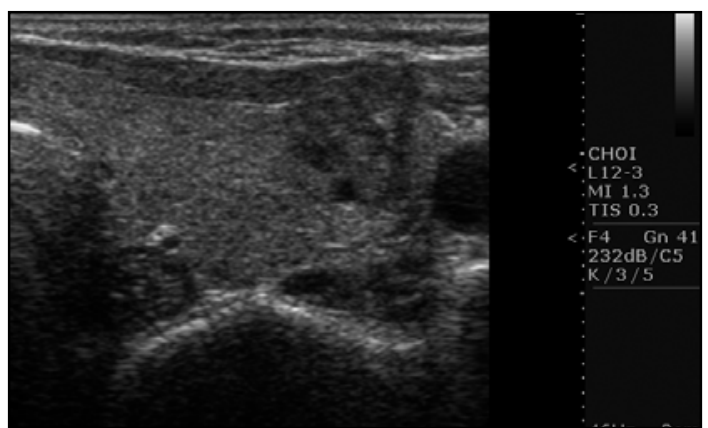

Fig. 9. Thyroid cancerinvading thyroid capsule.

Table 1. Ultrasonographic findings of thyroid nodules

\begin{tabular}{lcccc}
\hline Sonographic parameters & $\begin{array}{c}\text { Malignant }(\%) \\
(\mathrm{N}=89)\end{array}$ & $\begin{array}{c}\text { Benign }(\%) \\
(\mathrm{N}=64)\end{array}$ & $\begin{array}{c}\text { Total } \\
(\mathrm{N}=153)\end{array}$ & $\mathrm{p}$ value \\
\hline Calcific ation & $53(59.6 \%)$ & $6(9.3 \%)$ & 59 & 0.00 \\
Imegular margin & $44(49.4 \%)$ & $7(10.9 \%)$ & 51 & 0.00 \\
More tall than wide & $30(33.7 \%)$ & $5(7.8 \%)$ & 35 & 0.00 \\
Capsule invasion & $8(7.8 \%)$ & $1(1.6 \%)$ & 9 & 0.052 \\
\hline
\end{tabular}

Table 2. Multiple logistic regression analysis of ultra sonographic parameters

\begin{tabular}{lccccc}
\hline & Estimate & SE & p-value & OR & $95 \% \mathrm{Cl}$ \\
\hline Calcific ation & 2.227 & 0.512 & 0.000 & 9.268 & $3.398-25.273$ \\
Irregular margin & 1.288 & 0.550 & 0.019 & 3.626 & $1.233-10.662$ \\
More tall than wide & 0.594 & 0.636 & 0.350 & 1.811 & $0.521-6.301$ \\
Capsule invasion & 0.401 & 1.346 & 0.766 & 1.494 & $0.107-20.882$ \\
\hline
\end{tabular}

SE : standard emor, OR : odds ratio, $\mathrm{Cl}$ : confidence interval 
무정형 석회화군 27예 중 25예(92.6\%)에서 악성소견 을 보여 점상 석회화 뿐 아니라 무정형 석회화군도 악성 을 예측하는 소견으로 유용할 것으로 생각된다. 초음파변 수들을 이용한 갑상선 유두선암의 진단에 관한 Koike 등 ${ }^{10)}$ 의 연구에서 민감도, 특이도 및 양성 예측율을 각각 $76.0 \%, 92.2 \%, 80.6 \%$ 를 보고하고 있다.

\section{여포선암}

여포선암의 경우 여포선종과 세침흡인검사로도 감별이 어렵고, 초음파검사로 감별이 어려운 것으로 알려져 있 다. 초음파 검사상 halo가 없고, 낭종성 변성이 없고, 저 에코성, 불규칙한 변연부, 석회화를 보일 경우는 여포선암 으로 추측할 수 있으며(Fig. 10), 이 경우에는 강력히 수 술을 권유해야 한다. 또한 최근 여포선암의 경우 조직의 탄성도가 떨어지는 것을 이용하여 탄성도를 측정하는 초 음파검사(elastography)가 있으므로 이를 활용하는 것 도 도움이 될것으로 생각된다.

\section{림프종}

원발성 림프종은 드물며, 하시모토 갑상선염에 동반되 어 잘 발생한다. 하시모토 갑상선염 환자에서 갑작스럽 게 갑상선종이 커질 경우 림프종을 의심하여야 한다. 림 프종의 초음파 소견은 하시모토 갑상선염에 동반된 저 에코성 음영과 비균질 에코 및 종괴 후방에 증가된 에코 가 특징이다(Fig. 11).

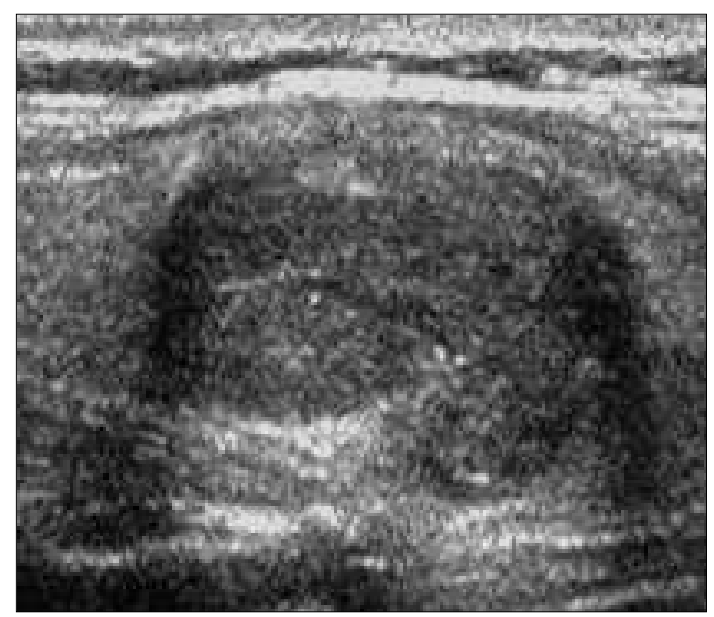

Fig. 10. Follic ular tumor with imegular marg in and calcification.
수질암

갑상선 수질암은 모든 갑상선 암의 약 1 5\%를 차지 하는 드문 악성 종양으로, 약 $75 \%$ 에서는 산발적으로 발 생하며, $25 \%$ 에서는 유전성으로 발생된다. ${ }^{11)}$ 유전성 갑 상선 수질암은 갑상선 수질암, 부갑상선 선종 및 갈색세 포종을 특징으로 하는 제 $2 \mathrm{~A}$ 형 다발성 내분비선종 $(\mathrm{MEN}$ $2 \mathrm{~A})$ 과 갑상선 수질암, 갈색세포종, 점막성 신경종을 특 징으로 하는 제 $2 \mathrm{~B}$ 형 다발성 내분비선종 $(\mathrm{MEN} 2 \mathrm{~B})$ 와 다 른 내분비 장애를 동반하지 않는 가족성 갑상선 수질암 (Familial medullary thyroid cancer, FMTC) 3가지로 나누어진다. 산발적으로 발생한 갑상선 수질암은 가족력 이 없고 50 대나 60 대에 발견되고 대부분 단일 결절이 동반되는 반면(Fig. 12), 유전성 갑상선 수질암은 양측 에 발생하며 주변 림프절에 침범을 잘 한다고 한다(Fig. 13). 수질암의 초음파 소견은 점상의 밝은 echogenic foci 가 종양의 내부에 관찰된다(Fig. 12). 병리학적으로 보면 이것은 아미로이드에 둘러싸인 칼슘이 침착된 것이다. ${ }^{2)}$

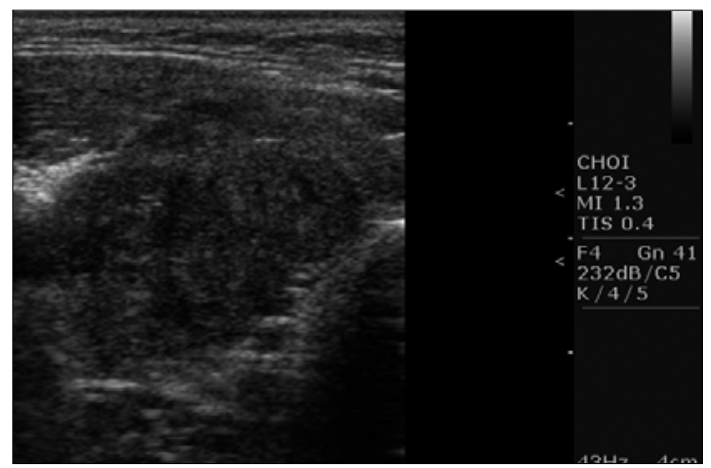

Fig. 11. Lymphoma.

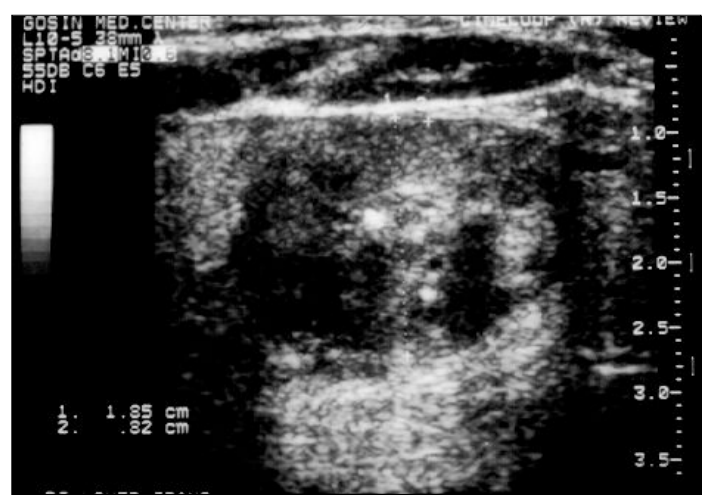

Fig. 12. Sporadic medullary carcinoma. 


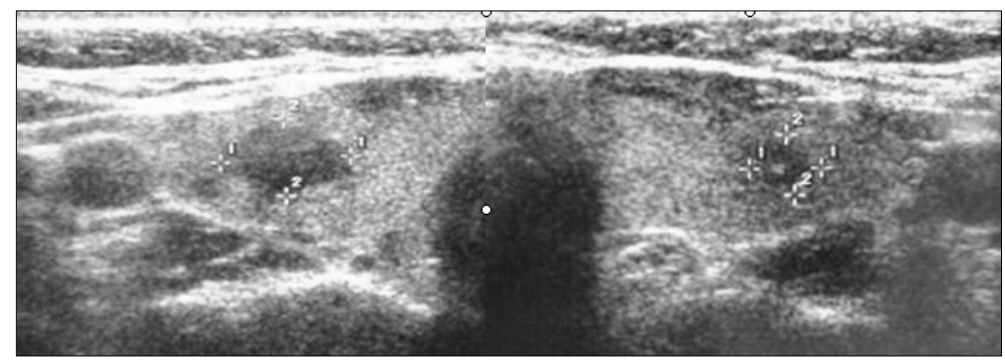

Fig. 13. Bilateral medullary carcinoma in multiple endocrine neoplasia $2 \mathrm{~A}$.

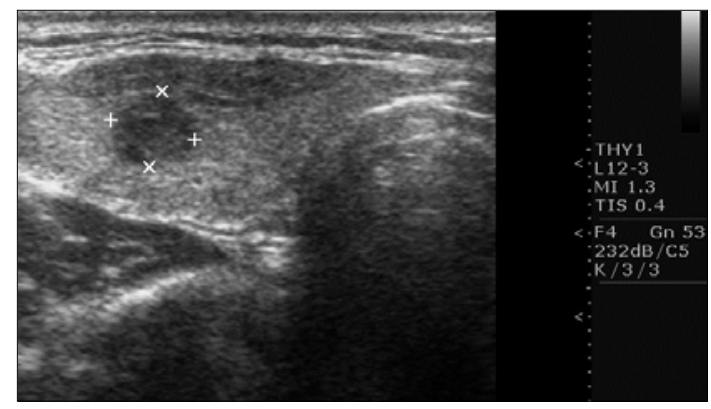

Fig. 14. Medullary carcinoma diagnosed by fine needle aspiration.

초음파 검사상 이러한 소견을 보일 경우 calcitonin을 검 사하면 되고, $\mathrm{CEA}$ 가 높으나 소화기계에 종양이 발견되 지 않을 경우 수질암을 의심해보는 것이 임상에서 매우 유용하다. 반면 특징적인 칼슘의 침작을 보이지 않는 경 우도 있어 진단이 쉽지 않다(Fig. 14).

\section{림프절전이}

갑상선암이 전이된 경부 림프절의 초음파검사 소견 현 재 $1 \mathrm{~cm}$ 이상의 림프절 종대, 종경과 횡경의 비가 2이하, 또는 단경과 장경의 비가 0.7 이상, 중심부 에코선 소실, 불규칙한 변연부들 가진 낭종성 종대 및 내부 석회화 등이 악성을 시사하는 소견으로 제시되고 있다(Fig. 15). ${ }^{13) 14)}$

\section{비결절성(미만성) 갑상선 질환의 초음파 소견}

갑상선 초음파검사는 결절성 갑상선질환 뿐 아니라 비 결절성 (미만성) 갑상선질환의 진료에도 도움이 된다. 본 란에서는 갑상선염과 그레이브스씨 병 등의 감별진단에 도움이 되는 초음파 소견을 간략히 기술하려고 한다.

\section{급성 갑상선염}

갑상선 농양은 매우 드문 질환으로 상기도염이나 중이
염등 선행하는 감염질환의 후유증으로 생기거나 양배꼴 동루(pyriform sinus fistula) 나 갑상설루(thyroglossal duct cyst)등 해부학적 이상으로 생긴다. 초음파 검사 소견은 시기에 따라 차이가 보인다. 시간이 지나 농양이 형성되면 진단이 쉽다. 또한 세침검사를 하게 되면 pus 를 확인할 수 있다(Fig. 16).

아급성 갑상선염(Subacute thyroiditis)

아급성 갑상선염은 상기도 감염 후 전경부에 압통과 갑 상선중독증 증상을 동반하는 질환으로 확진에는 RAIU 를 측정하여야 한다. 그러나 아급성 갑상선염 환자의 경 우 임상증상과 갑상선기능검사 및 특징적인 초음파소견 을 이용하면 진단이 가능하다. 갑상선이 경도로 종대되 어 있고 불규칙한 저에코역이 보이고(Fig. 17A), probe 를 대면 압통을 호소한다. 추적관찰시 염증이 소견의 개 선과 함께 초음파소견도 호전된다(Fig, 17B).

\section{무통성 갑상선염}

무통성 갑상선염은 아급성 림프구성갑상선염 또는 출 산 후에 잘 발생하므로 산후갑상선염이라고도 한다. 무 퉁성 갑상선염의 초기 갑상선호르몬의 방출 증가로 환자 는 갑상선중독증 증상을 보이고 갑상선기능검사도 항진 증의 소견을 보여 그레이브스씨 병과 감별이 요한다. 이 때 doppler를 이용하면 감별진단에 도움이 된다. 특히 산후에 모유 수유 중에는 RAIU를 시행할 수 없어 감별 진단이 어려우나 doppler는 태아에 해가 없으므로 아주 유용하다(Fig. 18).

\section{만성갑상선염}

하시모토 갑상선염의 경우는 갑상선이 전반적으로 커 져있고, 표면이 불규칙하며, 내부 echo는 불균일한 소견 
J Clinical Otolaryngol 2007;18: 144-151

Fig. 15. Papillary carcinoma with lymphnode metastasis

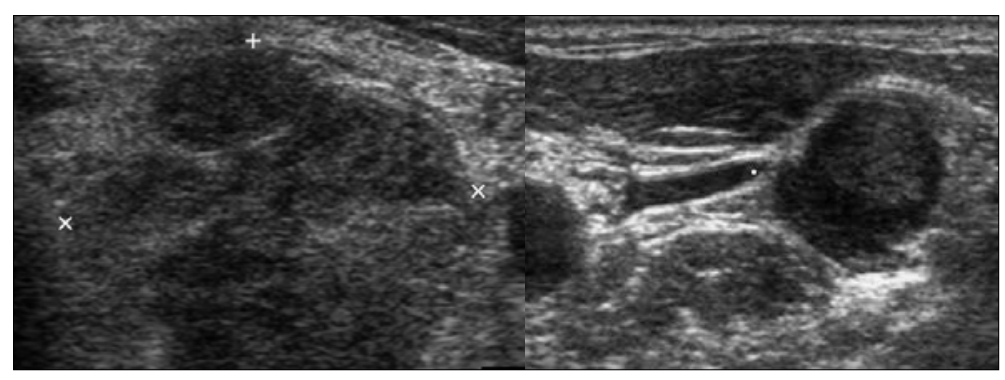

Fig. 16. A patient of acute suppurative thyroiditis.
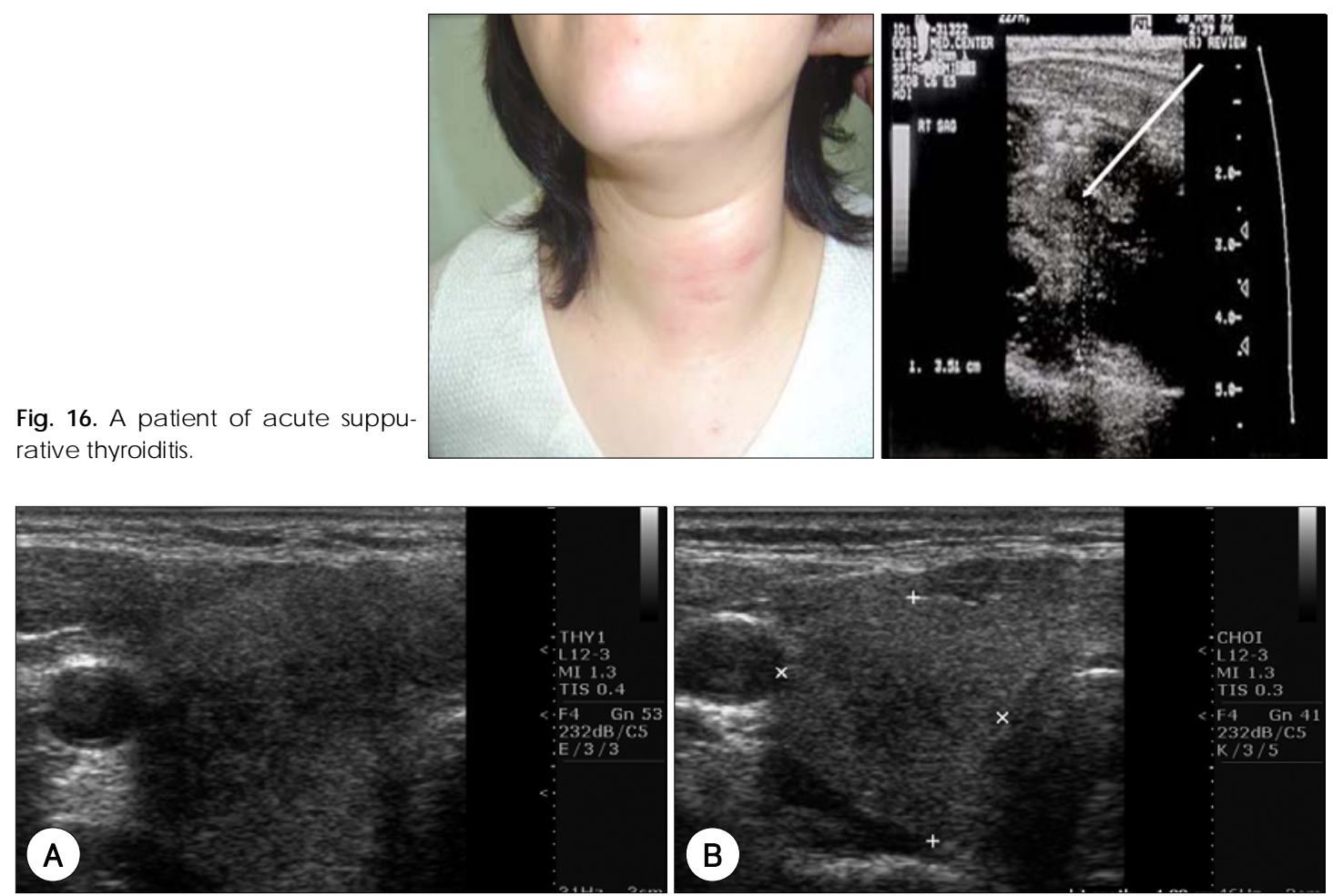

Fig. 17. Ultra sonography of subacute thyroiditis patient (on our hospital day (A), and follow-up 2 months later (B)) .
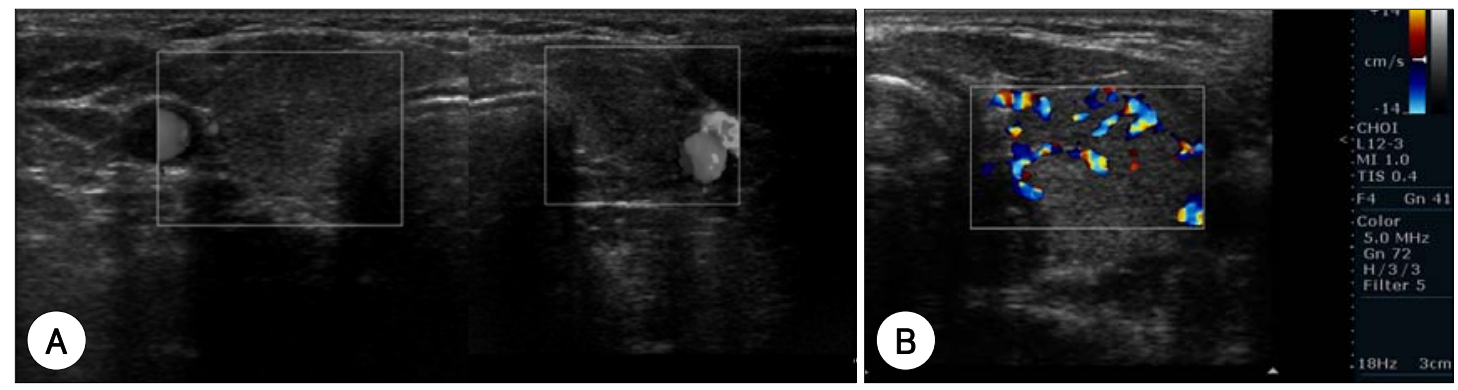

Fig. 18. Color doppler pictures of painless thyroiditis (A) and Graves' disease (B). 

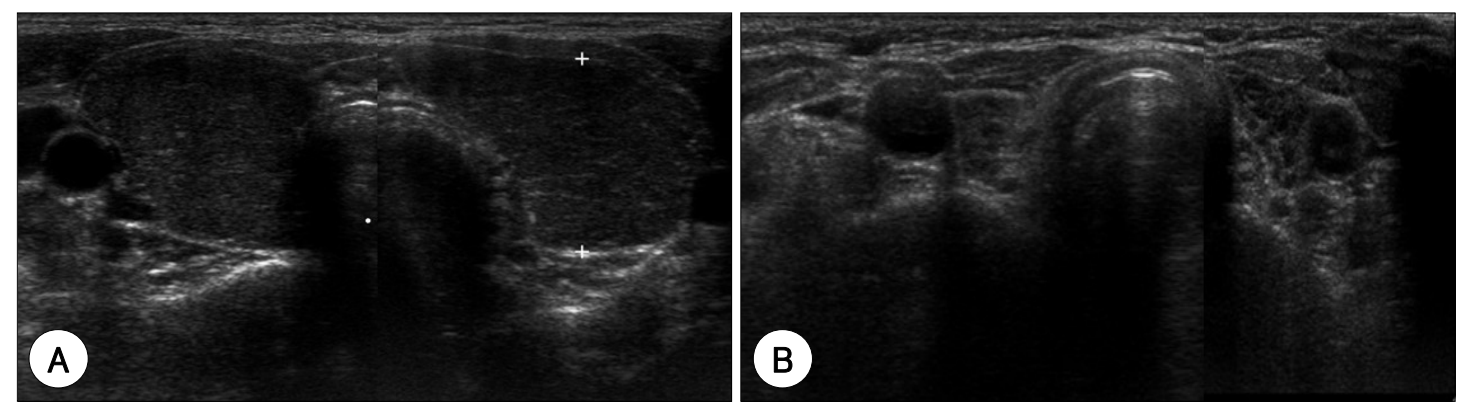

Fig. 19. Two types of chronic thyroiditis, Hashimoto's thyroitis (A), and atrophic thyroiditis (B).

을 보인다(Fig. 19A). 반면 위축성 갑상선염의 경우는 갑상선이 작아져 있다(Fig. 19B).

\section{요 약}

2003, 2005년 발표된 국내의 보고에 따르면 그해에 가장 증가된 암이 갑상선암이며, 그 원인은 갑상선암의 진단의 증가에 의한다고 한다. 이는 최근 갑상선 초음파 검사가 외래검사에서 많이 시행되고 있으며, 유방암 검진 시 초음파검사의 증가도 원인으로 작용했을 것으로 생각 된다.

여러 갑상선질환에 대한 초음파 검사소견을 짧은 지 면에 다 설명하기는 한계가 있으나, 중요하다고 생각되는 부분에 대해서는 언급을 하였다. 마지막으로 임상에서 중 요한 팁을 말하고자 한다면, 필자의 경험상 간혹 초음파 검사는 악성소견을 보이나, 세침흡인세포검사의 결과는 양성으로 나올 때, 세침흡인검사를 다시 시행하거나, 수 술을 해보면 악성으로 진단되는 경우를 가끔 경험해본다. 그러므로 갑상선암을 예측하는 인자로서 높은 민감도, 특 이도 및 정확도를 보이는 초음파 변수들을 활용하면 임상 에서 갑상선암을 진단하는데 도움이 될 것으로 생각된다.

\section{중심 단어 : 갑상선 초음파 · 갑상선종양 - 갑상선질환.}

\section{REFERENCES}

1) Baskin HJ. Thyroid ultrasound-just do it. Thyroid 2004;14: 91-2.

2) van Herle AJ, Rich P, Ljung BE, Ashcraft MW, Solomon
DH, Keeler EB. The thyroid nodule. Ann Int Med 1982;96: 221-32.

3) Vander JB, Dawber TR. The significance of nontoxic thyroid nodules. Final report of a 15-year study of the incidence of thyroid malignancy. Ann Intern Med 1968;69:537-40.

4) DeGroot LJ, Kaplan EL, MaCormick M, Strauss FH. Natural history, treatment, and course of papillary thyroid carcinoma. J Clin Endocrinol Metab 1990;71 (2):414-24.

5) Molitch ME, Beck JR, Derisman M, Gottlieb J, Pauker G. The cold thyroid nodule: an analysis of diagnostic and therapeutic options. Endocr Rev 1984;2:185-99.

6) Tomimori EK, Camargo RY, Bisi H, Medeiros Neto G. Combined ultrasonographic and cytological studies in the diagnosis of thyroid nodules. Biochimie 1999;81:447-52.

7) Rago T, Vitti P, Chiovato L, Mazzeo S, De Liperi A, Miccoli P, et al. Role of conventional ultrasonography and color flow-doppler sonography in predicting malignancy in cold thyroid nodules. Eur J Endocrinol 1998;138:41-6.

8) Takashima S, Morimoto S, Ikezoe J. CT evaluation of anaplastic thyroid carcinoma. Am J Roentgenol 1990;154:1079.

9) Takashima S, Fukuda H, Nomura N. Thyroid nodules. reevaluation with ultrasound. J Clin Ultrasound 1995;23:179.

10) Koike E, Noguchi $S$, Yamachita H, Murakami T, Ohshima A, Kawamoto H, et al. Ultrasonographic characteristics of thyroid nodules; prediction of malignancy. Arch Surg 2001; 136 (3):334-7, Radiology 1988;168:769-72.

11) Ezaki H, Ebihara S, Fujimoto Y, Iida F, Ito K, Kuma K, et al. Analysis of thyroid carcinoma based on material registered in Japan during 1977-1986 with special reference to predominance of papillary type. Cancer 1992;70 (4):808-14.

12) Gorman B, Charboneau JW, James EM, Reading CC, Wold LE, Grant CS, et al. Medullary thyroid carcinoma: role of high-resolution US. Radiology 1987;162 (1 Pt 1):147-50.

13) Vassallo P, Wernecke K, Roos N, Peters PE. Differentiation of being from malignant superficial lymphadenopathy. Radiology 1992;183 (1):215-20.

14) Evans Rm, Ahuja A, Metreweli C. The linear echogenic hilus in cervical lymphadenopathy. A sign of benignity or malignancy? Clin Radiol 1993;47:262-4. 